\title{
QUALITY EVALUATION SCHEMES FOR AGRICULTURAL PRODUCTS AND FOODSTUFFS IN POLAND IN PREVIOUS AND PRESENT FINANCIAL PERSPECTIVE OF EU
}

\author{
Antoni Mickiewicz ${ }^{1}$, Bartosz Mickiewicz ${ }^{2}$ and Wojciech Gotkiewicz ${ }^{3}$ \\ ${ }^{1}$ Professor emeritus; ${ }^{2}$ West Pomeranian University of Technology in Szczecin, Faculty of Economics; ${ }^{3}$ University \\ of Warmia and Mazury in Olsztyn, Faculty of Environmental Management and Agriculture
}

\begin{abstract}
The study presents quality schemes for agricultural products and foodstuffs that have been developed since the EU was founded. The schemes were based on the need to strive for diversification of agricultural production, to identify ways to increase the market value of products, while protecting consumers against inaccurate information on the ways and methods of production. The implementation of schemes has been described in the Polish context and on the example of two measures included in the next financial perspectives. The RDP 2007-2013 has been identified as using financial instruments at a low level. It means that the beneficiaries are not interested in activities related to the quality of agricultural products. In addition, the implementing body (ARR - Agricultural Market Agency) has not taken advantage of all the opportunities for encouraging beneficiaries to switch to quality production. The call for applications within the RDP 2014-2020 suggests a possibility of failure to meet specific indicators at the level of 25.9 thousand, due to the adopted criteria and difficulties in accessing the support.
\end{abstract}

Keywords: quality of agricultural production, financial perspective, financial instruments, participation of beneficiaries.

JEL code: Q18.

\section{Introduction}

Quality schemes for agricultural products and foodstuffs have taken on a completely new meaning upon the increase of agricultural productivity and saturation of agricultural markets. As a result, consumers began to look for diversified agricultural products, especially those that were produced using traditional methods. It turned out that the promotion of products having specific characteristics brings significant benefits to the rural economy, especially in less-favoured or remote areas, both by increasing farmers' incomes and by keeping the rural community in rural areas. In addition, the promotion of diversity and quality was a source of farmers' competitive advantage. It was a priority that the consumers were properly informed about the features of agricultural products and how they were produced through information on product labels. The main goal of the EU was to ensure agricultural production at a high level of food safety, which should be implemented at all stages of the food chain. This, in turn, was a guarantee of a high level of consumer and environmental protection, accompanied by the increase in the competitiveness of the food industry (Mickiewicz A. 2011).

\section{The subject, purpose and scope of research}

For many years, Poland has shown a high food deficit, hence so little attention having been paid to quality. It is true that the 1970s saw the first discussions about food safety in the country, but it was not reflected in applying the standards or the conditions of production at all stages of the food chain. The Polish market of products characterized by high quality agricultural production has been developing only for several years (the period after Poland's accession to the EU can be seen as a turning point). As a result of signing the Treaty of Accession, Poland implemented all legal acts related to the common agricultural policy, including those concerning the development of quality schemes for agricultural products and foodstuffs (Chylek E., 2012).

\footnotetext{
1 Zolnierska 47, 71-210 Szczecin, antoni.mickiewicz@zut.edu.pl

2 zolnierska 47, 71-210 Szczecin, bartosz.mickiewicz@zut.deu.pl

3 Oczapowskiego 2, 10-719 Olsztyn, wgot@uwm.edu.pl
} 
The main purpose of the study was to present European regulations on food quality schemes, that regulate all issues related to the protection of designations of origin and geographical indications, labelling and distribution of traditional agricultural products. The Rural Development Programme for 2007-2013 included an analysis of two measures that had been addressed to beneficiaries willing to strengthen their position on the market by promoting their traditional products. The RDP 2014-2020, on the other hand, included a characterization of two measures related to the support for accession to quality schemes and the support of producer groups in the field of information and promotion.

The study was based on European and national regulations, rural development programmes, the management information system of the Agency for Restructuring and Modernisation of Agriculture (Polish: ARiMR), and publications in this field. The research was carried out as part of statutory research conducted at the Faculty of Economics at the West Pomeranian University of Technology in Szczecin in 2018.

\section{European regulations on quality schemes for agricultural products and foodstuffs}

The institutional and organizational framework for the quality of agricultural products was created by the European Community issuing further guidelines defining the objectives and directions of changes in agricultural policy in this area. First of all, it was stressed that the quality policy for agricultural products is part of the Common Agricultural Policy. This policy gives EU producers a competitive advantage and contributes to the protection of cultural heritage. These features are a result of the skills and determination of EU farmers and producers who preserve their traditions, while taking into account the latest changes in production methods and raw materials. It was found that consumers display a growing demand for high-quality products that are produced using traditional methods. Therefore, the quality policy aims to preserve the diversity of agricultural production and also increases the demand for agricultural products or foodstuffs having specific characteristics, in particular related to their geographical origin (Chyek E., 2012).

Since the 1980s, EU regulations have provided for a scheme for the protection of designations of origin and geographical indications for agricultural products and foodstuffs. In 1992, the EU adopted a harmonized regulatory framework to allow the registration of valued names of agricultural products and foodstuffs produced according to specifications in a given geographical area. The scheme of the guaranteed traditional specialties included a register of names of traditional specialties that are a derivative of the traditional composition or use of traditional production method (Council Regulation, 1992).

EU regulations lay down food and food safety requirements at all stages of production, including rules to ensure fair trade practices and information given to consumers. The agricultural product quality policy should therefore provide producers with the appropriate instruments to more effectively label and promote those of their products that have specific features, while protecting those producers against unfair practices.

The promotion and improvement of quality schemes in agriculture was announced in 'Europe 2020: A strategy for smart, sustainable and inclusive growth'. The strategy includes goals of creating a competitive economy based on knowledge and innovation, and supporting a high-employment economy that ensures social and territorial cohesion. The quality policy for agricultural products provides producers equipped with the right instruments to more effectively identify and promote those of their products that have specific characteristics, while protecting those producers against unfair practices (Regulation of the European Parliament and of the Council, 2010). 
Quality schemes are usually divided into two types: those based on certification and those based on labelling. Certification of products comes down to the possibility of awarding products with certificates confirming that a given product has a certain added value. The labelled products, on the other hand, must come from certified organic farms. Such label guarantees that the product meets the requirements of official supervision, comes directly from the manufacturer or has been prepared in a closed package and ensures that at least $95 \%$ of the product's ingredients have been produced organically. The European Union guarantees the credibility of organic farming products, regardless of where they are produced. A regional product of known origin receives a registration to support the manufacturers of products related to a given geographical area (Dobiezynski, 2013).

In order to maintain the diversity of agricultural products and ensure a balance between demand and supply, the European Union has introduced a nomenclature that is protected due to its origin or place of production. Protected Designation of Origin (PDO) is the name of a region (place) whose quality or properties are determined by the geographical environment. An additional requirement includes production and processing within the specific geographical area. Protected Geographical Indication (PGI), on the other hand, is the name of a region or a specific place (country) which has a specific quality, goodwill or other characteristic property, attribuTable to its geographical origin. Another legal act introduced the Traditional Specialities Guaranteed (TSG) which applies to a traditional agricultural product or foodstuff recognized by the community due to its specific character by being registered in the EU. Organic farming label has been introduced as well - it relates to the use of production methods compatible with the principles of organic production, based on the general system of farm management and food production, along with environmentally beneficial practices. Integrated production (IP), on the other hand, aims to protect plants while taking into account the cultivation system, the expectations of consumers and meeting high quality requirements (Regulation of the European Parliament and of the Council, 2012).

At the national level, the food quality scheme focuses on integrated production (IP), the scheme of traditional specialities guaranteed (TSG), and organic farming products. The Ministry of Agriculture adopted a national scheme of food quality, including "Jakosc i Tradycja” ("Quality and Tradition”) developed by the Polish Chamber of Regional and Local Products and the Union of the Provinces of the Republic of Poland, which is a system that uses only raw materials of traceable origin and components free from GMO. The Quality Meat Program (QMP) scheme developed by the Polish Association of Beef Cattle Producers is a system that guarantees the properties of a given production process. The Quality Assurance for Food Products (QAFP) scheme developed by the Union of Producers and Employers of the Meat Industry applies to multiple types of products: pork, poultry and cold cuts made of poultry, pork, and beef. The Pork Quality System (PQS) developed by the Polish Pig Breeders and Producers Association "POLSUS" and the "Polish Meat" Union imposes an obligation that guarantees characteristics features of a given production process on livestock producers (RDP, 2007).

Efficient schemes are mostly based on proper registration and control of protected products. Food quality schemes can be divided into community schemes (operating in all European Union member states) and national schemes (operating only in Poland). The European Union has two basic schemes of food labelling, promotion and protection: 1. an EU protection scheme for regional and traditional products, 2. an EU scheme for organic farming products. In Poland, trademarks and certification are approved by a commission under the competent minister in charge of the agricultural market. 
Measure: participation of farmers in food quality schemes (RDP 2007-2013)

The concept of making a Polish farmer more involved was reflected in a measure of Priority Axis 1 of the RDP 2007-2013. The measure was addressed only to those participants of the food quality scheme who actively participated in the production of high-quality agricultural products for consumption. The mechanism enabled agricultural manufacturers producing agricultural products within specific food quality scheme to recover the costs incurred for the inspections carried out on their farms. In addition, the measure allowed to obtain certificates confirming the quality of manufactured products, as well as cost reimbursement for premiums for producer groups, if the producers were associated (RDP, 2007).

The measure was aimed at improving the quality of production and agricultural products intended for human consumption, increasing the consumption of high quality food and supporting the farmers producing high quality food. The objective of the measure was implemented through financial support for farmers participating in food quality schemes. Beneficiaries could participate both in the Community system and the national system. The RDP 2007-2013 assumed that 69 thousand beneficiaries would participate in the measure. According to the information of the ARiMR Management Information System, the beneficiaries submitted 32.3 thousand applications, and 26.7 thousand $(82.7 \%)$ of them were successful.

Table 1

Participation of farmers in the food quality scheme (RDP 2007-2013)

\begin{tabular}{|l|c|c|c|}
\hline \multicolumn{1}{|c|}{ Province } & $\begin{array}{c}\text { Number } \\
\text { of applications } \\
\text { submitted }\end{array}$ & $\begin{array}{c}\text { Number of decisions } \\
\text { issued }\end{array}$ & $\begin{array}{c}\text { Amount of payments } \\
\text { made (in thousand } \\
\text { PLN) }\end{array}$ \\
\hline Dolnoslaskie & 1,161 & 922 & $1,421.6$ \\
\hline Kujawsko-pomorskie & 434 & 336 & 470.7 \\
\hline Lubelskie & 3,253 & 2,793 & $5,521.8$ \\
\hline Lubuskie & 1,014 & 897 & $1,753.3$ \\
\hline Lodzkie & 1,070 & 903 & $1,865.90$ \\
\hline Malopolskie & 3,071 & 2510 & $1,134.6$ \\
\hline Mazowieckie & 5,024 & 4,205 & $8,831.3$ \\
\hline Opolskie & 78 & 69 & 1105.5 \\
\hline Podkarpackie & 2,544 & 2,100 & $4,400.80$ \\
\hline Podlaskie & 4,301 & 3,771 & $7,440.5$ \\
\hline Pomorskie & 720 & 554 & $1,224.40$ \\
\hline Slaskie & 264 & 199 & 268.4 \\
\hline Swietokrzyskie & 2,084 & 1,838 & $4,175.5$ \\
\hline Warminsko-mazurskie & 3,991 & 3,235 & $4,848.2$ \\
\hline Wielkopolskie & 759 & 575 & $934,6.8$ \\
\hline Zachodniopomorskie & 2511 & 1,845 & $2,896.21$ \\
\hline Total & 32,279 & 26,752 & 51298.5 \\
\hline
\end{tabular}

Source: ARiMR Management Information System

The amount of payments made $(51,298.5$ thousand) allowed to provide each beneficiary with support amounting to PLN 1,372.3.

The indicative budget of the RDP 2007-2013 initially planned the amount of 100 million euro for the measure in question. As a result of the evaluations carried out by the programme monitoring committee of the Ministry of Agriculture and Rural Development, the funds were not spent as intended and the original objectives were amended. As a result, the level of support dropped to EUR 14 million, which was enough to cover the costs of payments made. According to the ECB (PLN 4.2 per euro), we will get EUR 12.4 million, i.e. the support was implemented at the level of $88.6 \%$ and 
compared to the original objective - at the level of $12.4 \%$. Such low level of use of financial instruments shows that the beneficiaries are not interested in activities related to the quality of agricultural products. Furthermore, the implementing entity (Agricultural Market Agency) has not made every effort to encourage beneficiaries to switch to quality production.

\section{Measures of the quality scheme for agricultural products and foodstuffs (RDP 2014-2020)}

The measures contained in RDP 2014-2020 relating to the quality scheme for agricultural products are a continuation of the measure contained in the previous financial perspective. The decision about the further implementation of financial assistance addressed to the participants of quality schemes was based on the fact that the Polish market of products with confirmed high and above-standard production quality was at a low level of development (RDP, 2014).

The scheme is aimed at improving the quality of production and agricultural products intended for human consumption, increasing the consumption of high quality food and supporting farmers producing high quality food. The objective of the measure was implemented through financial support for farmers participating in food quality schemes. The support is granted to the beneficiaries when they join a scheme for the first time and for a period not longer than five years.

Participation in a quality scheme involves additional costs resulting from the need to introduce necessary changes to the farm and making it open for any necessary inspections, in accordance with the scheme standards. The support was motivational and aimed at facilitating production in new conditions required by a specific quality scheme. The support was also aimed at allowing for the additional production costs to be covered until they are reflected in the higher prices of products on the market. The aid takes the form of a refund within 3 years of joining the quality scheme. It includes costs incurred when joining the quality scheme and an annual premium for participation in the scheme.

The amount of support was set at the maximum level of PLN 3,200 per year for products specified by the EU and at a maximum of PLN 3,000 for products within the organic farming scheme. The national scheme, on the other hand, provided for the support between PLN 1470 per year ('Quality and Tradition') and PLN 2,750 per year (IP). The catalogue of expenditures from the previous perspective has been expanded with the purchase of specialist publications and traps related to production within integrated crop production.

The measure "Quality schemes for agricultural products and foodstuffs" is implemented through two sub-measures, namely: 1 . Support for new participants of quality schemes that aim to increase farmers' participation in national quality schemes, 2. Support for information and promotion activities of promotional teams consisting of at least two producers. The support is motivational and aims to facilitate production in the new conditions required by a specific quality scheme. Preferential treatment applies to farms up to $5 \mathrm{ha}$, where fixed costs resulting from participation in quality schemes constitute a great financial burden. The aid is granted to an active farmer who participates in quality schemes, manufactures products intended for human consumption (directly or after being processed) and meets other specific conditions (Regulation of the Ministry of Agriculture and Rural

Development, 2015). 


\section{Participation of agricultural producer groups in the agricultural product quality schemes (2014-2020)}

\begin{tabular}{|l|c|c|c|}
\hline \multicolumn{1}{|c|}{ Province } & $\begin{array}{c}\text { Number of } \\
\text { applications } \\
\text { submitted }\end{array}$ & $\begin{array}{c}\text { Number of decisions } \\
\text { issued }\end{array}$ & $\begin{array}{c}\text { Amount of payments } \\
\text { made (in thousand } \\
\text { PLN) }\end{array}$ \\
\hline Dolnoslaskie & 41 & 7 & 54,6 \\
\hline Kujawsko-pomorskie & 111 & 39 & 269,0 \\
\hline Lubelskie & 249 & 34 & 290,6 \\
\hline Lubuskie & 24 & 4 & 32,2 \\
\hline Lodzkie & 144 & 40 & 304,5 \\
\hline Malopolskie & 182 & 13 & 112,2 \\
\hline Mazowieckie & 761 & 350 & 2874,3 \\
\hline Opolskie & 10 & 2 & 18,1 \\
\hline Podkarpackie & 91 & 14 & 124,4 \\
\hline Podlaskie & 76 & 19 & 165,7 \\
\hline Pomorskie & 23 & 1 & 0.00 \\
\hline Slaskie & 17 & 0 & 722,8 \\
\hline Swietokrzyskie & 230 & 87 & 326,7 \\
\hline Warminsko-mazurskie & 115 & 47 & 428,4 \\
\hline Wielkopolskie & 158 & 64 & 150,0 \\
\hline Zachodniopomorskie & 46 & 17 & 5872,6 \\
\hline Total & 2278 & 739 & \\
\hline Source & & & \\
\hline
\end{tabular}

Source: ARiMR Management Information System

According to the RDP 2014-2020, the above measures, which cannot be completed before 2023, have covered 25.9 thousand beneficiaries. The approved EU funds are implemented in accordance with the principle of shared management between the Member States and the European Union. The EAFRD share was set at $63.6 \%$, which requires a $36.4 \%$ increase in the involvement of the Treasury. According to the budget of the RDP 2014-2020, the EAFRD's resources were set at 21.0 million euro, and the overall level of the indicative budget - at 33.0 million euro, representing $0.2 \%$ of the total support instruments of the rural development programme (RDP, 2014).

\section{Summary}

The strategy adopted to support the quality of agricultural products in the EU sought to pay attention to new aspects of food production and safety. It meant getting back to traditional production methods that now are in the minority, while farmers get added value which is rewarded with a specific price. Concepts such as 'traditional food', 'organic food', 'local' or 'regional products' gain new importance. In this case, it means the restoration of forgotten flavours, aromas, appearance or shape and a production that uses local raw materials and old methods. Traditional production is done on a small scale, based on local ingredients, old machines or devices, in a non-industrial way. Traditional production is in opposition to mass unified production carried out by large manufacturing plants.

Through their activities and participation in quality schemes of agricultural products, beneficiaries were given the opportunity to inform consumers about the specific features of their products, the place of production and specifications of the product. The measure allowed to obtain certificates confirming the quality of manufactured products, and to refund the costs of premiums for producer groups.

It should be said, however, that the level of interest of Polish farmers in quality schemes for agricultural products is insufficient. The RDP 2007-2013 analysis showed a low level of use of financial instruments. This means that the beneficiaries are not interested in activities relating to the quality 
of agricultural products, including obtaining funds. In addition, the implementing entity (Agricultural Market Agency) did not take advantage of all the opportunities for encouraging beneficiaries to switch to quality production. On the other hand, the current course of the call for applications within the RDP 2014-2020 shows that there is a risk that particular indicators will not be performed at the level of 25.9 thousand, due to the adopted criteria and difficulties in accessing the support. This way, the programme might need to be modified in the next financial perspective, which should already be one of the topics for discussion on the future agricultural budget of the European Union.

\section{Literature}

1. Chylek, E. Uwarunkowania innowacyjnego rozwoju sektora rolno-zywnosciowego i obszarow wiejskich w ramach polityki rolnej (Determinants of innovative development of the agri-food sector and rural areas as part of agricultural policy). (2012). Agencja Reklamowo-Wydawnicza Arkadiusz Grzegorczyk, Warsaw, pp. 84-92

2. Dobiezynski, K. Ewolucja podejscia do jakosci zywnosci oraz podstawowe cechy systemow jakosci produktow rolnych i srodkow spozywczych w Unii Europejskiej (The evolution of the approach to food quality and the basic features of quality systems for agricultural products and foodstuffs in the European Union). Zeszyty Naukowe. (2013). SGGW No 3, Warsaw, pp. 54-67

3. Mickiewicz, A. Doradztwo w ocenie uzytkownikow rolniczych gospodarstw rodzinnych regionu zachodniopomorskiego (Extension service in the assessment of agricultural users of family farms in the West Pomeranian region). (2011). Agrobiznes - problemy negocjacji z Unia Europejska. Wyd. Adam Marszalek, Torun, pp. 64-73.

4. Rural Development Program (2007), Ministry of Agriculture and Rural Development, Warsaw.

5. Rural Development Program (2014), Ministry of Agriculture and Rural Development, Warsaw.

6. Regulation of the Minister of Agriculture and Rural Development of 8 June 2009 on specific conditions and procedure for granting and payment of financial support within the "Information and promotion activities" measure covered by the Rural Development Programme for 2007-2013 (2009). Ministry of Agriculture and Rural Development, Warsaw.

7. Regulation of the Minister of Agriculture and Rural Development of 6 August 2015 on specific conditions and procedure for granting, payment and reimbursement of financial support within the sub-measure "Support for accession to quality schemes" covered by the Rural Development Programme for 2014-2020. (2015). Ministry of Agriculture and Rural Development, Warsaw.

8. Council Regulation (EEC) No 2082/92 of 14 July 1992 on certificates of specific character for agricultural products and foodstuffs (1992). European Commission. Brussels.

9. Council Regulation (EC) No 510/2006 of 20 March 2006 on the protection of geographical indications and designations of origin for agricultural products and foodstuffs (2006). European Commission. Brussels.

10. Regulation (EU) No 1151/2012 of the European Parliament and of the Council of 21 November 2012 r. on quality schemes for agricultural products and foodstuffs (2012). European Commission. Brussels.

11. Proposal for a Regulation of the European Parliament and of the Council on quality assurance schemes for agricultural products (2010). European Commission. Brussels. 